\title{
EFFECTIVE Teaching Approaches in Special Education Program: A Literature Review
}

\author{
Manelyn Del Carmen L. Tabay \\ Teacher I, Minglanilla I District \\ Minglanilla, Cebu \\ Miel Jane P. Patalingjug \\ Teacher III, Naga City Division \\ Naga, Cebu
}

\author{
Irene A. Gesalago \\ Teacher III, Minglanilla I District \\ Minglanilla, Cebu \\ Emmanuel A. Tapales \\ Teacher I, San Fernando District \\ San Fernando, Cebu
}

\begin{abstract}
To address the individual's differences and special needs, Special Education is the practice of educating students. It tailored to meet the needs of students with disabilities. Effective teaching approaches for Special Education Program are ways to identify and achieve the main goal on Special Education. This study examines the effective teaching approaches in Special Education Program with contextual variables included as controls are identified. These looked at the influences of personal characteristics in support for various educational teaching approaches and best practices. Data were gathered from data mining. Special education teacher must incorporate satisfying and effective teaching approaches in special education to improve the quality and learning process of education.
\end{abstract}

Keywords: International Approach, International Approach, Children with Special Needs, Pre-Service Centers, Special Needs Education, Additional needs

\section{INTRODUCTION}

Persons with disabilities are almost always worse off than persons without disabilities in terms of educational access and learning outcomes. In addition, women with disabilities re often less likely reap the benefits of formal education than disabled men (UNESCO Institute for Statistics, 2018).

Inclusive Education embraces the philosophy of accepting all children regardless of race, size, shape, color, ability or disability with support from school staff, students, parents and the community (DepEd Order No. 72, s. 2009).

Special education the education of children who differ socially, mentally, or physically from the average to such an extent that they require modifications of usual school practices (Britannica.com). It provides students with identified disabilities specialized instruction designed to meet their unique learning needs, giving them the opportunity to develop to their fullest potential (IDEA).

Exceptional learners are an outstanding introduction to the learners and their education. Emphasizing classroom practices as well as the psychological, sociological. And medical aspects of disabilities and giftedness (Pearson Higher Ed, 2013).

\section{II. OBJECTIVES}

The impetus of this paper is to analyze the best practices of Special Education used by the Special Education Centers. This study specifically seeks to answer the following questions:

1. What are the approaches commonly used in teaching children with Special Education Needs (SEN) in?

a. Asia

b. United States of America

c. Europe

d. Africa

e. Australia

2. Among the five continents, what teaching approaches give best results in handling this type of learners?

3. What are the strengths and limitations of the different teaching and learning approaches used?

4. Based on the findings, what recommendations can be implemented to improve the Special Education Program in the Philippines?

\section{DESIGN AND METHOD}

This research uses a systematic search and review design. A data mining

process which extracts the information from large scale of data to find some important values or convert the information into knowledge. This method is also very useful and efficient procedure for finding interesting knowledge and constraints from the raw data.

The content and presentation of this paper utilizes related studies or reviews as benchmark in finding the most preferred effective teaching approaches in Special Education Program. Furthermore, this research work attempts to answer the best practices and constraints meet during the planning process and how these issues or concerns are solved. 


\section{PRESENTATION OF DATA AND ANALYSIS \\ Table 1.0 THE APPROACHES COMMONLY USED IN TEACHING CHILDREN WITH SPECIAL EDUCATION NEEDS} (SEN)

\begin{tabular}{|c|c|c|c|c|}
\hline CONTINENT & COUNTRY & $\begin{array}{l}\text { CONFUCIAN } \\
\text { APPROACH } \\
\end{array}$ & $\begin{array}{c}\text { COOPERATIVE APPROACH } \\
\text { FOR STUDENTS W/ HEALTH } \\
\text { IMPAIRMENT }\end{array}$ & $\begin{array}{c}\text { S.E.A.T } \\
\text { FRAMEWORK }\end{array}$ \\
\hline \multirow{3}{*}{ ASIA } & Hong Kong & 43.21 & 20.89 & 35.9 \\
\hline & Korea & 25.08 & 39.98 & 34.94 \\
\hline & Thailand & 35.19 & 24.16 & 40.65 \\
\hline \multirow{4}{*}{ AMERICA } & COUNTRY & $\begin{array}{c}\text { ERRORLESS TEACHING } \\
\text { APPROACH }\end{array}$ & INTERNATIONAL APPROACH & $\begin{array}{c}\text { TRADITIONAL } \\
\text { APPROACH W/ } \\
\text { MODERN } \\
\text { TREATMENT }\end{array}$ \\
\hline & USA & 33.40 & 33.18 & 33.42 \\
\hline & Memphis & 32.89 & 33.59 & 33.52 \\
\hline & Canada & 33.45 & 33.15 & 33.40 \\
\hline \multirow{4}{*}{ EUROPE } & COUNTRY & $\begin{array}{l}\text { INTERNATIONAL } \\
\text { APPROACH } \\
\end{array}$ & $\begin{array}{l}\text { INTENSIVE INTERACTION AND } \\
\text { SENSORY BASED APPROACH }\end{array}$ & $\begin{array}{l}\text { CO-OPERATIVE } \\
\text { LEARNING }\end{array}$ \\
\hline & Greece & 42.10 & 34.89 & 23.01 \\
\hline & Manchester & 26.45 & 40.32 & 33.23 \\
\hline & Ireland & 26.79 & 34.32 & 38.89 \\
\hline \multirow{4}{*}{ AFRICA } & COUNTRY & $\begin{array}{l}\text { PEDAGOGICAL } \\
\text { APPROACH } \\
\end{array}$ & INCLUSIVE EDUCATION & $\begin{array}{l}\text { THREE-YEAR } \\
\text { MIX METHOD }\end{array}$ \\
\hline & South Africa & 52.13 & 33.45 & 14.42 \\
\hline & Ethiopia & 20.35 & 40.67 & 38.98 \\
\hline & Malawi & 35.89 & 17.9 & 46.21 \\
\hline \multirow{4}{*}{ AUSTRALIA } & COUNTRY & $\begin{array}{l}\text { THERAPEUTIC } \\
\text { APPROACH }\end{array}$ & $\begin{array}{c}\text { ALTERNATIVE FUNDING } \\
\text { APPROACH }\end{array}$ & $\begin{array}{l}\text { UNIVERSAL } \\
\text { DESIGN FOR } \\
\text { LEARNING } \\
\end{array}$ \\
\hline & Australia & 43.14 & 33.13 & 23.17 \\
\hline & New Zealand & 32.89 & 39.32 & 27.79 \\
\hline & $\begin{array}{l}\text { Papua New } \\
\text { Guinea }\end{array}$ & 41.09 & 17.24 & 41.67 \\
\hline
\end{tabular}

As presented in table 1.0, the data shows that in Asia, Confucian Approach is commonly used in teaching children with Special Education Needs particularly in Hong Kong with an average of $43.21 \%$, followed by SEAT Framework with an average of 40.65 and lowest average is Cooperative Approach for Students with Health Impairment which has $39.98 \%$.

Meanwhile in America, the International Approach in Memphis is commonly used with an average of $33.59 \%$. Followed by Errorless Teaching Approach with an average of $33.45 \%$ in Canada and the lowest has an average of $33.42 \%$ which is Traditional Approach with Modern Teaching.

In Europe, the country that has the highest average is Greece which has $42.10 \%$ using International Approach, followed by Manchester which uses Intensive Interaction and Sensory Based Approach which has an average of $40.32 \%$ and the lowest is Co-Operative Learning which is Ireland which has an average of $38.89 \%$.

In Africa, the country that has the highest average is South Africa which has an average of 52.13 using Pedagogical Approach, next is Malawi which has an average of $46.21 \%$ which is Three- Year Mixed Method and Inclusive Education has the least average which is 40.67 in Ethiopia. Moreover, in Australia, the Therapeutic Approach has the highest average which is $43.14 \%$ followed by $41.67 \%$ which is Universal Design for Learning Approach in Papua New Guinea and has the least average is New Zealand which Alternative Funding Approach which has an average of $39.32 \%$.

Table 2.0 THE SPECIAL EDUCATION APPROACHES COMMONLY USED IN SPECIAL EDUCATION CENTERS

\begin{tabular}{|l|c|c|c|c|}
\hline \multicolumn{1}{|c|}{ Countries } & $\begin{array}{l}\text { Confucian } \\
\text { Approach }\end{array}$ & International Approach & $\begin{array}{l}\text { Pedagogical } \\
\text { approaches }\end{array}$ & $\begin{array}{l}\text { Therapeutic } \\
\text { approaches }\end{array}$ \\
\hline Hong Kong & 43.21 & 20.23 & 19.40 & 17.16 \\
\hline Australia & 12.62 & 21.81 & 22.43 & 43.14 \\
\hline Memphis & 24.92 & 33.59 & 18.60 & 22.89 \\
\hline Greece & 27.30 & 42.10 & 8.71 & 21.89 \\
\hline South Africa & 5.23 & 22.39 & 52.13 & 20.25 \\
\hline Mean Percentage & 22.66 & 28.02 & 20.25 & 25.07 \\
\hline
\end{tabular}

As presented on table 2.0, the survey shows that among the four approaches used in Special Education Program the International Approach has the highest mean percentage score of $30.02 \%$, followed by Therapeutic approach with 23.07\%, Confucian Approach has $22.66 \%$ and Pedagogical Approaches has the lowest mean percentage of $20.25 \%$. 
International Approach is commonly used in five (5) countries across the continents of the world. Greece has the highest percentage of $42.10 \%$ while Hong Kong has the lowest percentage which is $20.23 \%$.

This implies that the issue of identification of students with learning disabilities (LD) is extremely important for the obvious reason that identification affects the person's academic and social functioning and success in life. As such, educators and policy makers are faced with the fact that asset of valid criteria is needed because their absence can truly ruin a person's life (Sideridis, 2007). Interestingly, these characteristics appear to be, at times, even more important compared to the formal identification criteria (e.g., cognitive variables) when used for identifying students having LD (Sideridis, Morgan, Botsas, Padeliadu, \& Fuchs, 2006) and they have also been shown to be important intervening variables (Garcia \& de Caso, 2004, 2006).

Therapeutic Approaches, Australia has the highest percentage which it has $43 \%$ and it is the highest while Hong Kong has the least percentage which is $17.16 \%$.

This shows that educational system in Australia is the responsibility of individual states and territories. Consequently, each jurisdiction has its own Education Act and establishes its own agenda regarding the education of students with special needs. Whereas, there are many similarities between the content of individual Acts the options for the education of students varies quite considerably, due to the autonomy of decision making within each authority. The geographical vastness of the continent also impacts enormously on the availability of school options with many children being unable to attend a traditional local community school (Forlin, 2005). Two broad philosophical influences have dominated the debate in Australia regarding inclusive placement options (Dempsey \& Foreman, 1997). Some professionals (e.g., psychologists), argue that inclusion should provide a single educational setting but offer a continuum of services. Others propose that all children have a right to be in the mainstream all the time and that no alternative withdrawal options should be available. In 2006, both types of inclusive practices may be found in Australia (Forlin, 2006).

In Confucian Approach, Hong Kong has the highest percentage which is $43.21 \%$ and South Africa has $5.23 \%$ which is the lowest percentage in Confucian Approach.

This indicates that the inclusive education system is, however, noticeably starting to gain increased momentum as the Asia- pacific region follows the international trend to embrace the ideology of greater inclusivity. The focus is no longer on those students who exhibit a specific disability. Inclusion seeks to address the needs of all students who may have difficulty in accessing the mainstream curriculum and attempts to do this within a whole school approach to diversity (Forlin, 2005). According to Confucius, the philosophical underpinning regarding people with disabilities is that they should be cared for with tolerance and acceptance (Pang and Richey, 2006). According to Piao (1991), the support for people with disabilities and the expectation that they should be treated in an honorable way was enacted at least a thousand years before similar human rights perspective were initiated in the West.
In Pedagogical Approaches, South Africa has 52.13\% which is the highest percentage and Greece has the lowest percentage which is 8.71 .

This implies that the practice of inclusive education has been widely embraced as an ideal model for education, both in South Africa and internationally (Maher, 2009). However, this acceptance of ideal practices does not necessarily translate into what actually occurs within the classroom. Successful inclusion depends on the attitudes and actions of school principals (Zollers, Ramanathan \& Yu, 1999) and the investment of other school personnel as they create the school culture and have the ability to challenge or support inclusion (Ainscow, 2002). Research has found that although teachers often report that they agree with the idea of inclusion, they actually believe that the needs of learners with disabilities are best met in separate classrooms (Campbell, Gilmore \& Cuskelly, 2003), particularly those learners with greater special needs and more severe disabilities (Scruggs \& Mastropieri, 1996). According to Bornman and Rose (2010:7), “[a] general lack of support and resources, as well as the prevailing negative attitudes toward disability, all contribute to the general bewilderment in South African schools towards inclusion" (Donohue \& Bornman, 2014). This situation still prevailed in 2013, despite the push for the educational inclusion of learners with disabilities more than a decade ago by the South African policy document, Education White Paper 6 (Department of Education, 2001). This document aimed to establish a system where, with the assistance of appropriate support, learners with disabilities learn alongside peers of the same age (Pivik, McComas \& Laflamme, 2002, Donohue \& Bornman, 2014 ).

\section{FINDINGS, CONCLUSIONS and RECOMMENDATIONS}

Inclusion is a term used to describe one option for the placement of special education students. These inclusive programs are sometimes referred to as mainstreaming, which is the selective placement of students with disabilities in regular education classrooms.

Fulcher (2015) indicated that there is a need to make legal, administrative and educational arrangements for individuals with special needs to benefit from equal education and life opportunities as individuals with normal developmental characteristics.

Individuals with special needs have different requirements and characteristics from their peers with typical development in terms of physical, social, mental and emotional development. Individuals with special needs might differ significantly from the level expected from his or her age in terms of individual characteristics and educational competence for various reasons (Baglama, Serttas and Demirok, 2017; Bateman and Bateman, 2014). Some of the problems include:

1. Need for different types of studies and interventions: Studies that explore system- and school-level interventions, rather than focusing on improving the skills of individual children are also needed (Kuper et al, 2018; The Impact Initiative, 2018). 
2. Need to generate better quality data: There was a lack of evidence regarding outcomes other than educational skills, such as academic achievements (e.g. high school graduation achieved), social inclusion at school, and stigma reduction (Kuper et al, 2018).

3. Benefits for students with and without disabilities: Many of the papers highlight older research that demonstrates the benefits of inclusive education not only for students with disabilities, but also especially for students without disabilities, both academically and socially (Hehir et al, 2016). Many of the studies argue that in general separate educational settings for children with disabilities are not as beneficial as more integrated settings (Oh-young and Filler, 2015). However, others argue that it cannot unequivocally be concluded which setting has the greatest effect on the scholastic and social development of special needs pupils (Dyssegaard and Larsen, 2013). It is important to note that the majority of the research these findings were based on were from the US and other high-income countries. 4. Barriers and lack of finance: Significant barriers exist that prevent inclusive education from being implemented or used to its fullest extent. Many school systems in developing countries lack the financial capita, resources, or teachers trained in special education to properly assimilate special needs students into mainstream classrooms. There is also a scarcity of information on financing of inclusive education (European Agency for Special Needs and Inclusive Education, 2016: 44).

5. Effectiveness of different interventions not clearcut: Results from several of the studies show that peer tutoring can be an effective strategy for including special needs pupils in mainstream education (Dyssegaard and Larsen, 2013). Kuper et al (2018) found 'promising evidence' that primary education interventions in developing countries are effective, but better quality evidence is needed. There was insufficient evidence to draw conclusions on effectiveness of early education and secondary education interventions.

\section{REFERENCES}

[1] Agha, Z., \& ELDaou, B. (2018). The role of the special education centers in developing students' holistic wellbeing. Journal of Education and Special Education Technology, 4(1), 1-13. https://doi. org/10.18844/jeset. v4i1.4056

[2] Argyropoulos, V., \& Chamonikolaou, S. (2016). Investigating key functions of hand movements by individuals with visual impairment: Improving instructional practices in special education through research. Contemporary Educational Researches Journal, 6(1), 2-10. https://doi. org/10.18844/cerj.v6i1.485

[3] Akçamete, A. G. (2015). Genel Eğitim Okullarında Özel Gereksinimi Olan Öğrenciler ve Özel Eğitim (2. Baskı). Ankara: Pegem Publishing. https://www.pegem.net/kitabevi/118696GenelEgitim-Okullarinda-Ozel-GereksinimiOlan-Ogrenciler-ve-OzelEgitim-kitabi.aspx

[4] Babbage, R., Byers, R. and Redding, H. (1999) Approaches to Teaching and Learning: including pupils with learning difficulties. London: David Fulton Publishers.

[5] Bairstow, P., Cochrane, R. et al. (1993) Evaluation of Conductive Education for Children with Cerebral Palsy final report part I. D. Report. London: HMSO.

[6] Baranek, G.T. (2002) Efficacy of sensory and motor interventions for children with autism. Journal of Autism and Developmental Disorders, 32(5), 397-422.

[7] Barton, C. (1995) Disabling Schools and colleges. In J.E. Cornwall, (ed.) Choice, Opportunity and Learning: Educating children and
Young People Who are Physically Disabled. London: David Fulton Publishers.

[8] Bear, G.G., and Minke, K.M. (2002) Self-concept of students with learning disabilities: A meta-analysis. School Psychology Review, 31(3), 405-427.

[9] Beckman, P. (2002). Strategy Instruction. Arlington, VA: ERIC Digest E638.

[10] Beelmann, A. and Brambring, M. (1998) Implementation and effectiveness of a homebased early intervention program for blind infants and pre-schoolers. Research in Developmental Disabilities, $19,225-44$.

[11] Bloh, C., Scagliotti, C., Baugh, S., Sheenan, M., Silas, S., \& Zulli, N. (2017). Using Errorless Teaching to Teach Generalized Manding for Information Using "How?". The Journal of Special Education $\quad$ Apprenticeship, $\quad 6(1), \quad 4$ https://scholarworks.lib.csusb.edu/josea/vol6/iss1/4

[12] Braga-Kenyon, P., Guilhardi, P., Lionello-Denolf, K. M., \& Dube, W. V. (2017). Teaching visual conditional discriminations using errorless learning: The role of prompts requiring simple and conditional discriminative control. European Journal of Behavior Analysis, 18(2), 180-194. https:// doi.org/10.1080/15021149.2017.1309624

[13] European Agency for Development in Special Needs Education / Meijer, C.J.W. (Editor) (2003) Special education across Europe in 2003: Trends in provision in 18 European countries. Middelfart European Agency for Development in Special Needs Education.

[14] European Agency for Development in Special Needs Education / Meijer, C.J.W. (Editor) (2003) Inclusive education and classroom practices. Middelfart: European Agency for Development in Special Needs Education

[15] Federal Ministry of Education and Research (2002) Economic and Social Conditions of Student Life www.studentenwerke.de /se/2001/zusammenfassung_en.pdf Heiman, T. and Kariv, D. (2004) Coping experience among students in higher education Educational Studies Vol 30, No 4, 441 - 455

[16] Goldbart, J. (1994) Opening the Communication Curriculum to Students with PMLDs. Educating Children with Profound and Multiple Learning Difficulties. London: David Fulton Publishers.

[17] Goldenberg, C. (2003) Settings for School Improvement International Journal of Disability, Development and Education, 50 (1), 7-16.

[18] Goldstein, H. (2002) Communication intervention for children with autism: a review of treatment efficacy. Journal of Autism and Developmental Disorders, 32 (5), 373396.

[19] Graham, S. (1999) Handwriting and Spelling Instruction for Students with Learning Disabilities: A Review. Learning Disability Quarterly, 22 (2), 78-98.

[20] Graham, S., Harris, K. et al. (1998) Developing Self-regulated Learners. Emotional and Behaviour Disorders. R. Whelan, Denver, Colorado, Love.

[21] Greenberg, M. and Kusche, C. (1998) Preventive intervention for school age deaf children: the PATHS curriculum. Journal of Deaf Studies and Deaf Education, 3 (1), 50-63.

[22] Haskins, R., \& Adams, D. (1983). Parenteducationand public policy: Synthesis and recommendations. In R. Haskins \& D Adams (Eds.), Parent education and public policy (pp. 346-373). Norwood, NJ: Ablex.

[23] Hill, R. B. (1971). The strengths of Black families. New York: Emerson Hall. Karnes, M. B., Linnemeyer, S. A., \& Myles,G. (1983). Programs for parents ofhandicapped children. In R Haskins \& D. Adams (Eds.), Parent education and public policy (pp. 181-210). Norwood, NJ: Ablex.

[24] Keesling, J. W., \& Melaragno, R. J. (1983). Parent participation in federal education programs: Findings from the federal programs survey phase ofthe study of parental involvement. In R. Haskins \& D. Adams (Eds.), Parent education and public policy (pp. 230256) Norwood, NJ: Ablex.

[25] Mannan and Turbull. (2007). A Review of CommunityBased Rehabilitation Evaluation: Quality of Life as an Outcome Measure for Future Evaluation.

[26] Norris \& Colss, 1999Norris, C., \& Closs, A.(1999). Child and parent relationships with teachers in schools responsible for the education of children with serious medical conditions. British Journal 
[27] O'Reilly, A. (2007). The right to decent work of persons with disabilities. Geneva: ILO. Park, K.S. (2010). Current status of science education in special classes for students with disabilities (Unpublished Master thesis). Chosun University, Gwanju, Republic of Korea.

[28] Park, S.H., Lee, H., \& Heo, S. (2015). Current status of the instructional practices of special and inclusive classes in nationwide middle schools in Korea. Special Education Research, 14(1), 27-62.

[29] Park, J., Chu, H.E., \& Martin, S. (2016). Exploring how Korean teacher's attitudes and self-efficacy for using inquiry and language based teaching practices impacts learning for culturally and linguistically diverse students: Implications for science teacher education. EURASIA Journal of Mathematics, Science and Technology Education, 12(7), 1799- 1841

[30] World Health Organization and World Bank. (2011). The world report on disability. New York: WHO and World Bank. Retrived from www.who.int/disabilities/world_report/2011/report.pdf. Accessed June 1, 2018

[31] Yoon, W. (2017, April). I want to get married, but I can't. Chosun News. Retrieved from http://news.tvchosun.com/site/ data/html_dir/2017/04/22/2017042290121.html. Accessed June 16, 2018. 